ZOOLOGIA 28 (3): 379-387, June, 2011

doi: $10.1590 /$ S1984-46702011000300012

\title{
Cerrado ground-dwelling ants (Hymenoptera: Formicidae) as indicators of edge effects
}

\author{
Carlos Roberto F. Brandão, 2; Rogério R. Silva \& Rodrigo M. Feitosa
}

\author{
${ }^{1}$ Museu de Zoologia, Universidade de São Paulo. Avenida Nazaré 481, 04263-000 São Paulo, SP, Brasil. \\ E-mail: rogeriorosas@gmail.com; rfeitosa@usp.br \\ 2 Corresponding author: E-mail: crfbrand@usp.br
}

\begin{abstract}
Large-scale agricultural production in Brazil preferentially occupies plateaus reclaimed from areas originally covered by Cerrado (savanna). Depending on the region, a percentage of the pristine vegetation coverage must be preserved by law, resulting in the creation of fragmented legal Cerrado reserves. The geometry of these relatively small legal reserves creates new habitat edges and ecotones, whose effects on the invertebrate fauna are poorly understood. This study aimed to assess the effects of abrupt edges resulting from soy production on ground-dwelling ant assemblages in the Brazilian Cerrado. The study sites are located within the Amazon region, in the state of Maranhão, northern Brazil, but were covered by Cerrado on a relatively low plateau, irregularly inter-spaced with gallery forests along streams. We compared species richness and species composition of ground-dwelling ants along eight transects set 0 , $50,100,150,200$, and $250 \mathrm{~m}$ into the sensu stricto Cerrado and 50 and $100 \mathrm{~m}$ into the soy field. The collecting periods covered the wet and dry seasons. Effects on ant species richness were non-significant, although composition of the assemblages was significantly affected by edge effects, which were, in part, found to be species specific. We hypothesize that edge effects are probably greater than estimated because of the shape and complexity of reserves. Consideration of edge effects in the Cerrado Biome should enable the design of appropriate reserve sizes and shapes to meet conservation goals.
\end{abstract}

KEY WORDS. Consevation; diversity; legal reserves; savanna; soy production.

The Brazilian Cerrado (a savanna like vegetation) once occupied some 2 million square kilometers, representing about $21 \%$ of the Brazilian territory (BRIDGewater et al. 2004). The Cerrado was recently recognized as one of the world hotspots for biodiversity conservation (MYeRs et al. 2000) because of its high endemism and rates of biodiversity loss due to recent human occupation and agricultural expansion; however, only $2.2 \%$ of its area is under legal protection (KLINK \& MACHADO 2005). The relatively high level of landscape conversion to agriculture is a major threat to the conservation of Cerrado's biodiversity. It is estimated that around $55 \%$ of the biome has been already deforested (KuINK \& Machado 2005, Silva et al. 2006).

Habitat edges are a ubiquitous feature of modern fragmented landscapes and have profound influences on the spatial distribution of many species (EwERS \& DidHAm 2008). Edge effects induce different micro-environmental conditions from those of the forest interior. These are mainly related to relative humidity, air and soil temperature, soil moisture, light incidence, soil organic matter, and pH (MARCHAND \& Houle 2006), which in turn influence species number, species composition, and population abundances of plants and animals (LAURANCE \& Yensen 1991, Laurance 2000, Zheng \& Chen 2000).
Abrupt edges, characterized by small spatial extensions between patches of different land use practices, are a major attribute of agricultural landscapes (DAUBER \& WOLTERs 2004), and some available studies suggest that sharp edges markedly impact the structure and distribution of faunal communities (Ingham \& Samways 1996, French \& Elliot 1999). In the Cerrado, abrupt edges have been created by agricultural expansion, including regions in the Brazilian Amazon that have been cleared for soybean production. The law dictates that at least $50 \%$ of these regions are protected and kept intact as conservation reserves. In Brazil, fragmentation and edge effects have been mainly reported for Amazonian forests (e.g. Malcolm 1994, Ferraz et al. 2003, Laurance et al. 2006) and Brazilian Atlantic forest (e.g. Viana et al. 1997, TABARELli et al. 1999), but very few comparative data are available for Cerrado (Pivello et al. 1999). Due to its unique physiognomy and often open structure, which permits enough sunlight to reach the lower strata, Cerrado is likely to exhibit different edge effect responses when compared to other Neotropical forests and savannas (Pivello et al. 1999). Despite the ecological importance of this biome, there is no available study on the effects of abrupt edges, created by agricultural expansion, on the invertebrate fauna of the Cerrado. 
In this study, we examine the edge response of grounddwelling ants to recently created legal reserves of Cerrado. Our study aimed to understand the response of ant communities at the sharp edges between Cerrado areas exposed to soy bean land use. Ants have been successfully employed as ecological bioindicators because they are ubiquitous, relatively abundant, diverse, of great functional importance, easily surveyed by baiting and other quantitative techniques, readily collected in suitable numbers for statistical analysis, and are easily identified to morphospecies (Agosti et al. 2000, ANdersen \& Majer 2004). Further, ants are of special interest because they are an important part of the biodiversity, influencing other organisms and soil process (Agosti et al. 2000).

Specifically, we investigate (1) how species richness, assemblage composition, and species abundance respond at selected distances from the edge in two areas of the Brazilian Cerrado, and (2) the characteristic ant species of the soy culture, edge and interior habitat, revealing ant indicator taxa of edge effects.

\section{MATERIAL AND METHODS}

\section{Study sites and ant sampling}

Between 1995 and 2000, the PRODECER program, a joint venture of the Brazilian government, via the Ministério da Agricultura e Abastecimento and the Japanese Cooperation Agency, has funded 47 agroindustrial project areas, each at least 40,000 ha in size. Several of these areas are located in what is called by the Brazilian government as "legal Amazon", covering areas suitable and non suitable for mechanized agriculture, which includes different savanna habitats.

This study was carried out from 1999 to 2000 in the Colonization Project of the municipality of Balsas, state of Maranhão, northern Brazil. The study site lies within a structurally complex range known as Chapada das Mangabeiras, a system of low plateaus and low undulations that represent water catchments between the Tocantins and Parnaíba River Basins. The region is regarded as an important corridor between the Amazon forest and the peculiar Caatinga biome (Progea 1995). According to Embrapa soil maps (JACOMINE 1986), the landscape is dominated by yellow latosols (sandy-argillaceous) with small patches of podozolic red-yellow soils and laterite. Because the legal reserves are mostly situated on sandy areas, the soil is well drained, dystrophic, and mostly acidic. Elevation in the study sites ranged from 520 to $560 \mathrm{~m}$ above sea level. The climate is seasonal, characterized by a well-defined dry season (May to September), with minimum monthly average rainfall close to $60 \mathrm{~mm}$ and average minimum temperature of $18^{\circ} \mathrm{C}$ (June to July). In the wet season (Semptember to April), the average rainfall is $1,118 \mathrm{~mm}$ and average maximum temperature is $26^{\circ} \mathrm{C}$. The average annual rainfall in the municipality of Balsas is $1,216.7 \mathrm{~mm}$.

The areas surveyed are all within, or neighboring, conservation reserves included in the PRODECER agroindustrial project area. Because they are usually delimited as to leave the best spots for agricultural use, these legal reserves have different sizes and shapes, often including steep slopes and lacking extensive flat areas. The original vegetation of all study areas can be classified as sensu stricto Cerrado, a predominantly tree and scrub phytophysiognomy presenting two strata of woody vegetation, with an herbaceous stratum; the upper-layer of vegetation is $2-6 \mathrm{~m}$ high and discontinuous. The bare soil was estimated to represent $10-25 \%$ of the area (Progea 1995). Although poorly studied, this area of Cerrado is very rich in at least two taxonomic groups: surveys lasting three years (19951998) in four sites found 773 moth species from 32 nocturnal Lepidoptera families (CAMARGO 1998); a floristic survey revealed 63 tree and 483 herb and shrub species (Joel L. de Queiroga, Universidade Estadual de Londrina, unpubl. data).

Edge effects on ground-dwelling ants were investigated at edges of two recently established legal reserves, hereafter called reserve $1\left(08^{\circ} 37^{\prime} 27.1^{\prime \prime} \mathrm{S}, 46^{\circ} 44^{\prime} 30.5^{\prime \prime} \mathrm{W}\right)$ and reserve 2 $\left(08^{\circ} 34^{\prime} 19.6 \mathrm{~S}, 46^{\circ} 42^{\prime} 28.2^{\prime \prime} \mathrm{W}\right)$. Soy culture dominates the plateaus adjacent to these reserves, and the abrupt edges are created by natural ravines. At the point where we recorded geographic coordinates, the distance between sites is $6.89 \mathrm{~km}$.

Eight $200 \mathrm{~m}$ transects were set parallel to the edge between soy culture and preserved Cerrado at each study site. Each was randomly set along the edge lengths, spaced 0, 50, $100,150,200$, and $250 \mathrm{~m}$ into sensu stricto Cerrado vegetation, and 50 and $100 \mathrm{~m}$ into the soy culture area (hereafter called -100 and $-50 \mathrm{~m}$ ). Within each $200 \mathrm{~m}$ transect, 20 sardine baits were distributed, with at least $10 \mathrm{~m}$ between them. Sardine baits were offered for 60 minutes, based on other studies in the Brazilian Cerrado (BRANDÃo et al. 2000, Silva et al. 2004). The collecting period covered the wet and dry seasons in the region (respectively 6-9 November 1999 and 16-17 March 2000). Altogether we surveyed sixteen transects in the two areas, collecting 20 baits in each, thus totaling 640 baits.

All ants taken while visiting the sardine baits were sorted and up to three workers of each morphospecies, pin mounted and labelled. The specimens were identified to morphospecies based on characters previously established to be important at the species level for each genus. When possible, names were linked to these morphospecies using taxonomic descriptions and by comparison with identified material deposited in the Formicidae collection of the Museu de Zoologia da Universidade de São Paulo, Brazil, where voucher specimens were deposited.

\section{Data analysis}

We employed species richness and species composition analyses to evaluate the response of ground-dwelling ant species to edges in the Cerrado. Samples from two seasons were pooled for the numerical analysis because baiting in different seasons was conducted at the same points of the transects. The number of species occurrences at the baits was used to compare ant assemblages among transects because occurrence often yields a more accurate estimation of abundance than the total num- 
ber of ant individuals collected at baits, since different species employ different systems of nestmates recruiting. Species occurrences and species richness were defined as the total number of species occurrences and the number of ant species occurring at transects, respectively. The number of ant species in each reserve was estimated using the Chao 2 index (Colwell 2008).

Because we did not consider the number of individuals at baits for the analysis, edge effects were tested using species presence-absence data. We applied three approaches to investigate patterns of species richness and composition at each edge distance. First, we evaluated the relationship between edge and species richness in each reserve using general linear models (GLMs), with distance of edge as an explanatory variable and species richness at baits as a response variable, taking into consideration Poisson errors (Crawley 2002). Second, detrended correspondence analysis (DCA) was used to show patterns in ant assemblages with respect to distance from edge. DCA is considered the best indirect ordination procedure to discern sample variation in response to environmental gradients (PIELOU 1984). Lastly, indicator species analysis (DufrêNe \& Legendre 1997) in the labdsv Package version 1.3-1 (RoBERTs 2009) assesses the habitat preferences of ant species for edge zones defined by NCAP analysis (results not showed; ANDERSON et al. $2005)$ as: interior $(100,150,200$, and $250 \mathrm{~m})$, edge (0 and 50 $\mathrm{m})$, and soy culture $(-100$ and $-50 \mathrm{~m})$. Indicator species analysis calculates an indicator value (\%) for each species, where 0 represents no indication and 100 represents perfect indication of the habitat. The indicator value combines information about species relative abundance (specificity) and relative frequency of occurrence (fidelity) in each of the edge zones (Dufrêne \& Legendre 1997, McGeoch et al. 2002).

\section{RESULTS}

\section{Overall species richness and species occurrence}

A total of 938 records of 77 species were obtained in 640 baits (Tab. I). In total, 34 ant species were recorded in both sites, 60 in the Cerrado reserve 1 and 52 in the Cerrado reserve 2. The Chao $2 \pm$ standard deviations estimated a species richness of 82 $( \pm 13.90)$ and $64( \pm 8.81)$ for Cerrado reserve 1 and Cerrado reserve 2 , respectively. The six most common species made up $45.15 \%$ of all ants collected at baits and were encountered in both studied reserves: Ectatomma brunneum Smith, 1858 (96 occurrences), Linepithema cerradense Wild, 2007 (92), Pheidole sp. 1 (84), Pheidole sp. 4 (74), Camponotus crassus Mayr, 1862 (73), and Dorymyrmex pyramicus (Roger, 1863) (42) (Tab. I).

\section{Edge-interior gradients in species richness and diversity}

The relationships between distance from edge into the Cerrado and species richness or species occurrences generally increased (Figs 1 and 2). The largest values of observed species richness, occurrences and diversity occurred at $100 \mathrm{~m}$ from the edge in reserve 1 , although the trend was less clear in reserve 2.
Ant species richness at baits did not differ significantly between edge and the interior transects in the Cerrado reserves (GLMs, $\mathrm{p}>0.05$ ). Only the $100 \mathrm{~m}$ transect in reserve 1 was significantly different, with higher mean species richness than the edge $(\mathrm{z}$-value $=2.531, \mathrm{p}=0.0114$, Tab. II). Inspection of the species list in each transect indicates the specific differences in species richness among habitats. In reserve 1, 52 ant species were found between edge and $100 \mathrm{~m}$ from the edge, while 36 species were found towards the interior of the reserve. In this case, the greater species richness in transects near the edge was related to the higher diversity of the Myrmicinae ant genera: Crematogaster, Pheidole, Solenopsis, and fungus-growers (Attini). However, there was no difference between species richness of edge and the interior in reserve 2 ( 35 and 37 species in edge and interior, respectively).
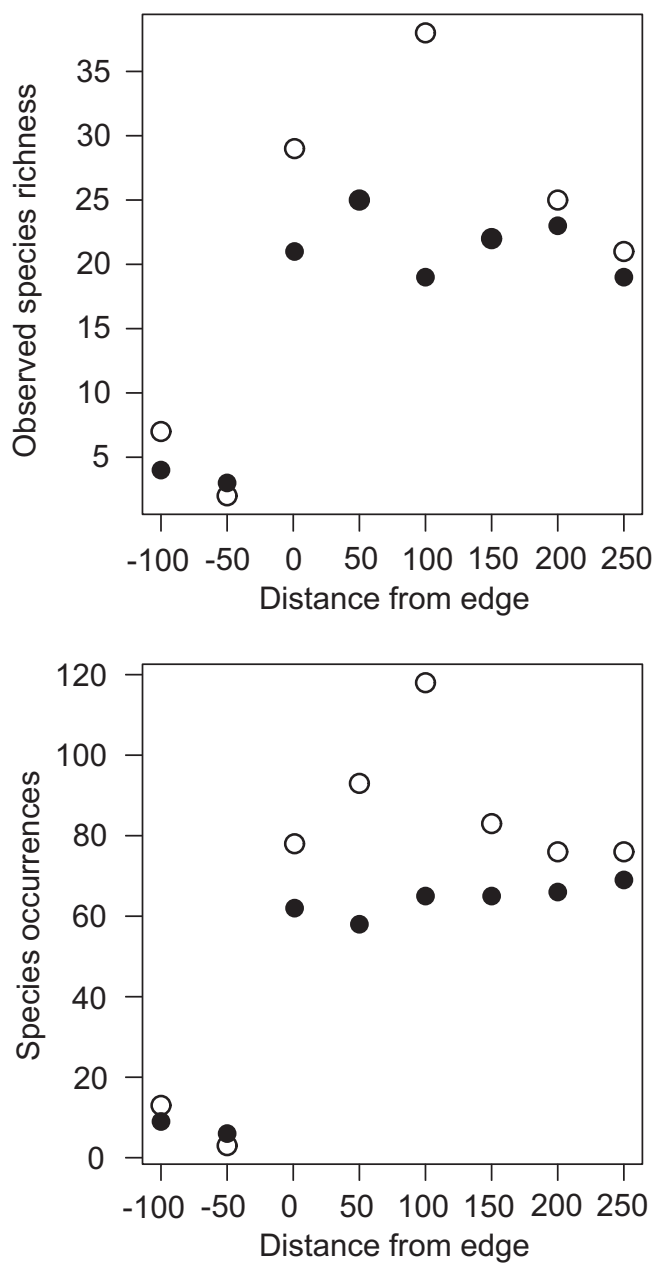

Figures 1-2. Relationships between distance from edge and: observed species (1) and species occurrences (2) for ground-dwelling ant assemblages in two surveyed Cerrado reserves. $(\bigcirc)$ reserve 1, (@) reserve 2, in Balsas, Maranhão, northern Brazil. 
Table I. Ground-dwelling ant species recorded (total number of occurrences) at sardine baits ( $\mathrm{N}=320$ per reserve; see Material and Methods) set along eight $200 \mathrm{~m}$ transects in two reserves of Cerrado in Balsas, Maranhão, northern Brazil.

\begin{tabular}{|c|c|c|c|c|c|c|c|}
\hline & $\begin{array}{c}\text { Reserve } \\
1\end{array}$ & $\begin{array}{c}\text { Reserve } \\
2\end{array}$ & $\begin{array}{c}\text { Total } \\
\text { occurrences }\end{array}$ & & $\begin{array}{c}\text { Reserve } \\
1\end{array}$ & $\begin{array}{c}\text { Reserve } \\
2\end{array}$ & $\begin{array}{c}\text { Total } \\
\text { occurrences }\end{array}$ \\
\hline Dolichoderinae & & & & Carebara (gr. Concinna) sp. 1 & 1 & 0 & 1 \\
\hline Azteca alfari Emery, 1893 & 0 & 3 & 3 & Cephalotes atratus (Linnaeus, 1758) & 1 & 2 & 3 \\
\hline Dorymyrmex brunneus Forel, 1908 & 0 & 1 & 1 & Cephalotes pavonii (Latreille, 1809) & 2 & 0 & 2 \\
\hline Dorymyrmex jheringi Forel, 1912 & 2 & 3 & 5 & Cephalotes pusillus (Klug, 1824) & 0 & 13 & 13 \\
\hline Dorymyrmex pyramicus (Roger, 1863) & 28 & 14 & 42 & Crematogaster abstinens Forel, 1899 & 2 & 14 & 16 \\
\hline Dorymyrmex spurius Santschi, 1929 & 0 & 4 & 4 & Crematogaster acuta (Fabricius, 1804) & 2 & 6 & 8 \\
\hline Dorymyrmex thoracicus Gallardo, 1916 & 1 & 0 & 1 & Crematogaster erecta Mayr, 1866 & 0 & 2 & 2 \\
\hline Dorymyrmex sp. 2 & 1 & 3 & 4 & Crematogaster evallans Forel, 1907 & 2 & 7 & 9 \\
\hline Dorymyrmex sp. 6 & 1 & 3 & 4 & Mycocepurus goeldii (Forel, 1893) & 2 & 0 & 2 \\
\hline Dorymyrmex sp. 8 & 4 & 1 & 5 & Nesomyrmex brasiliensis (Kempf, 1958) & 1 & 0 & 1 \\
\hline Gracilidris pombero Wild \& Cuezzo, 2006 & 0 & 2 & 2 & Ochetomyrmex semipolitus Mayr, 1878 & 0 & 5 & 5 \\
\hline Forelius brasiliensis (Forel, 1908) & 1 & 5 & 6 & Pheidole sp. 1 & 35 & 49 & 84 \\
\hline Forelius maranhaoensis Cuezzo, 2000 & 3 & 0 & 3 & Pheidole sp. 2 & 3 & 0 & 3 \\
\hline Forelius sp. 2 & 2 & 0 & 2 & Pheidole sp. 3 & 0 & 1 & 1 \\
\hline Linepithema cerradense Wild, 2007 & 51 & 41 & 92 & Pheidole sp. 4 & 48 & 26 & 74 \\
\hline Linepithema neotropicum Wild, 2007 & 5 & 5 & 10 & Pheidole sp. 5 & 8 & 2 & 10 \\
\hline Linepithema sp. 1 & 3 & 6 & 9 & Pheidole sp. 7 & 1 & 4 & 5 \\
\hline Linepithema sp. 2 & 0 & 1 & 1 & Pheidole sp. 8 & 11 & 0 & 11 \\
\hline Tapinoma melanocephalum (Fabricius, 1793) & 3 & 9 & 12 & Pheidole sp. 10 & 1 & 0 & 1 \\
\hline Ecitoninae & & & & Pheidole sp. 11 & 1 & 0 & 1 \\
\hline Labidus coecus (Latreille, 1802) & 0 & 1 & 1 & Pheidole sp. 14 & 1 & 0 & 1 \\
\hline Ectatomminae & & & & Pheidole sp. 15 & 8 & 0 & 8 \\
\hline Ectatomma brunneum Smith, 1858 & 66 & 30 & 96 & Pheidole sp. 16 & 1 & 1 & 2 \\
\hline Ectatomma edentatum Roger, 1863 & 7 & 1 & 8 & Pheidole sp. 18 & 5 & 0 & 5 \\
\hline Ectatomma muticum Mayr, 1870 & 8 & 0 & 8 & Rogeria scobinata Kugler, 1994 & 1 & 0 & 1 \\
\hline Ectatomma opaciventre (Roger, 1861) & 20 & 1 & 21 & Solenopsis sp. 1 & 11 & 14 & 25 \\
\hline Ectatomma planidens Borgmeier, 1939 & 7 & 7 & 14 & Solenopsis sp. 2 & 20 & 7 & 27 \\
\hline Gnamptogenys ammophila Lattke, 1990 & 3 & 1 & 4 & Solenopsis sp. 3 & 1 & 7 & 8 \\
\hline Formicinae & & & & Solenopsis sp. 4 & 1 & 0 & 1 \\
\hline Brachymyrmex longicornis Forel, 1907 & 10 & 7 & 17 & Solenopsis sp. 5 & 1 & 0 & 1 \\
\hline Brachymyrmex patagonicus Mayr, 1868 & 27 & 2 & 29 & Solenopsis sp. 6 & 6 & 0 & 6 \\
\hline Camponotus blandus (Smith, 1858) & 9 & 14 & 23 & Solenopsis sp. 7 & 3 & 0 & 3 \\
\hline Camponotus crassus Mayr, 1862 & 46 & 27 & 73 & Trachymyrmex bugnioni (Forel, 1912) & 0 & 1 & 1 \\
\hline Camponotus personatus Emery, 1894 & 17 & 14 & 31 & Wasmannia auropunctata (Roger, 1863) & 12 & 13 & 25 \\
\hline Camponotus renggeri Emery, 1894 & 6 & 0 & 6 & Ponerinae & & & \\
\hline Nylanderia fulva (Mayr, 1862) & 1 & 0 & 1 & Dinoponera gigantea (Perty, 1833) & 5 & 0 & 5 \\
\hline Paratrechina longicornis Latreille, 1802 & 0 & 1 & 1 & Odontomachus bauri Emery, 1892 & 1 & 0 & 1 \\
\hline Myrmicinae & & & & Pachycondyla villosa (Fabricius, 1804) & 0 & 1 & 1 \\
\hline Acromyrmex landolti (Forel, 1885) & 0 & 1 & 1 & Pseudomyrmecinae & & & \\
\hline Acromyrmex rugosus (Smith, 1858) & 1 & 0 & 1 & Pseudomyrmex termitarius (Smith, 1855) & 2 & 5 & 7 \\
\hline Atta sexdens (Linnaeus, 1758) & 6 & 2 & 8 & Pseudomyrmex flavidulus (Smith, 1858) & 0 & 2 & 2 \\
\hline Blepharidatta conops Kempf, 1967 & 0 & 4 & 4 & Total of records & 539 & 399 & 938 \\
\hline Cardiocondyla emeryi Forel, 1881 & 0 & 3 & 3 & Total of species & 60 & 52 & 77 \\
\hline
\end{tabular}


Table II. Model parameters (intercepts) for edge effects on ant ground-dwelling ant species richness at baits in two Cerrado legal reserves, as estimated from a generalized linear model, using Poisson errors ( $\mathrm{SE}=$ standard error; parameter estimates given are on the log scale; note that positive/negative parameter estimates indicate positive/negative effects relative to the edge intercept, which represents average ant species richness at baits).

\begin{tabular}{ccccc}
\hline & Parameters & SE & z-value & $P$ \\
\hline Reserve 1 & & & & \\
Edge & 1.348 & 0.114 & 11.829 & 0.000 \\
$50 \mathrm{~m}$ & 0.178 & 0.154 & 1.152 & 0.249 \\
$100 \mathrm{~m}$ & 0.375 & 0.148 & 2.531 & 0.011 \\
$150 \mathrm{~m}$ & 0.075 & 0.158 & 0.474 & 0.635 \\
$200 \mathrm{~m}$ & -0.013 & 0.162 & -0.081 & 0.936 \\
$250 \mathrm{~m}$ & -0.013 & 0.162 & -0.081 & 0.936 \\
Reserve 2 & & & & \\
Edge & 1.100 & 0.129 & 8.510 & 0.000 \\
$50 \mathrm{~m}$ & -0.034 & 0.184 & -0.184 & 0.854 \\
$100 \mathrm{~m}$ & 0.065 & 0.180 & 0.359 & 0.719 \\
$150 \mathrm{~m}$ & 0.033 & 0.181 & 0.181 & 0.856 \\
$200 \mathrm{~m}$ & 0.049 & 0.180 & 0.270 & 0.787 \\
$250 \mathrm{~m}$ & 0.110 & 0.178 & 0.621 & 0.535 \\
\hline
\end{tabular}

\section{Edge-interior similarity in species composition}

Results for DCA analysis suggest marked differences between edge and interior transects (the ordered transects along the first axis); further, in general, the first axis exhibited grouping of interior transects ( 150 to $250 \mathrm{~m}$, at least for reserve 2). The second axis shows additional species turnover among 100, 150 , and $200 \mathrm{~m}$ transects for reserve 1 (Fig. 3) and species turnover among 50, 150, and $200 \mathrm{~m}$ for reserve 2 (Fig. 4).

Indicator species analysis revealed the species-specific edge responses of ants for the three edge zones: field (-100 and $-50 \mathrm{~m})$, edge ( 0 and $50 \mathrm{~m})$, and interior $(100,150,200$, and 250 $\mathrm{m})$ of Cerrado. Five species, Brachymyrmex patagonicus Mayr, 1868, Ectatomma opaciventre (Roger, 1861), C. crassus, L. cerradense, and Wasmannia auropunctata (Roger, 1863) (reserve 2) were classified as indicator species characteristic of Cerrado interior. In contrast, two species were classified as characteristic of soy culture (Cardiocondyla emeryi Forel, 1881 and Solenopsis sp. 1). The edge showed the highest number of characteristic single habitat ant species (seven species) (Tab. III).

\section{DISCUSSION}

We found evidence of edge effects on species composition in the ground-dwelling ant communities of the studied reserves in the Cerrado biome. There was a significant difference in species composition in recorded baits scale (sampling
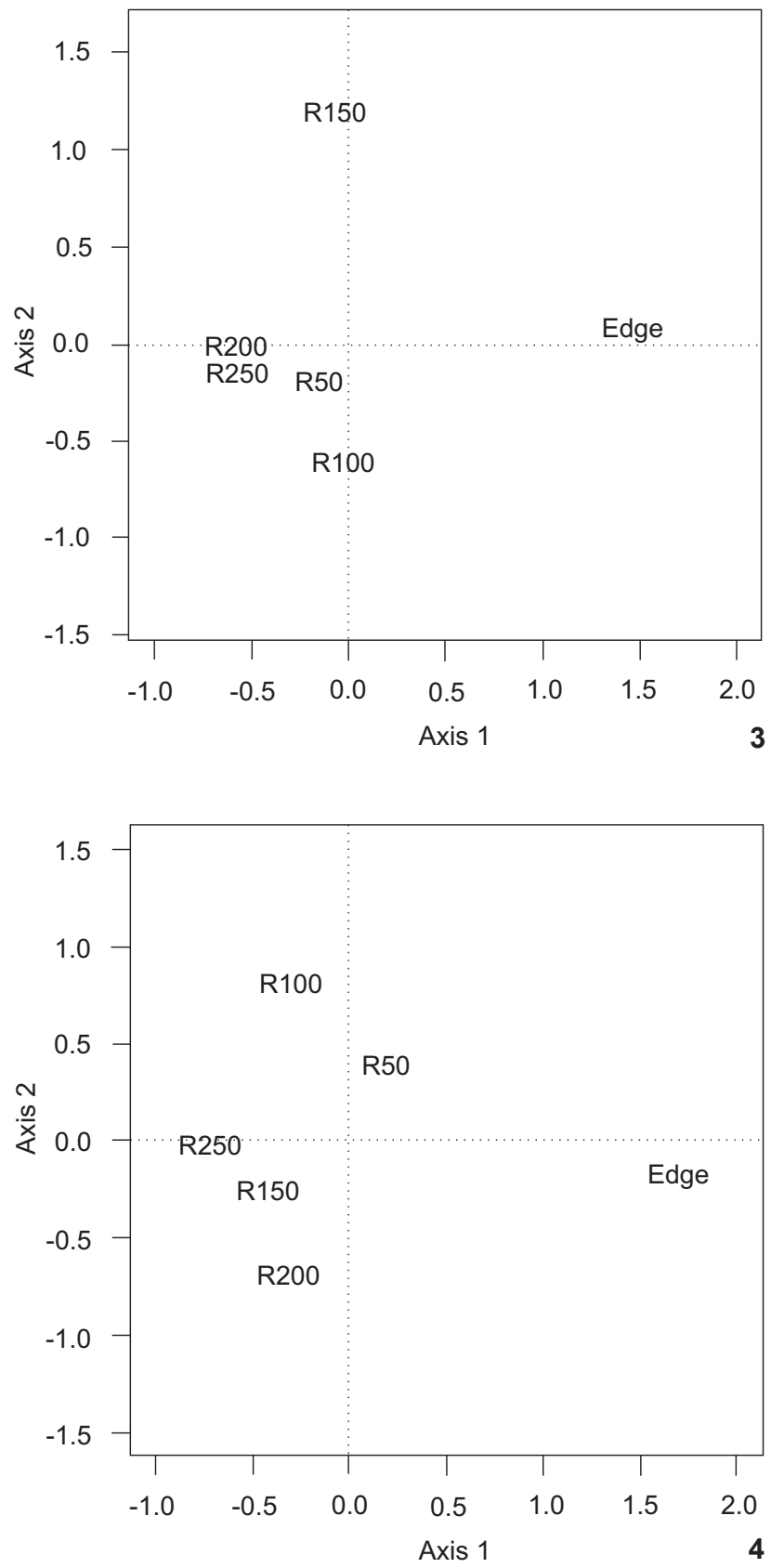

Figures 3-4. Detrended correspondence analysis (DCA) of baited transects in Cerrado reserve 1 (3) and Cerrado reserve 2 (4) in Balsas, Maranhão, northern Brazil, according to their ground-dwelling ant species assemblages composition.

unit). However, there was little evidence for a significant difference in overall species richness between the edge and the interior at the recorded scale transect or at baits scale, with relatively more species in the edge sites. 
Table III. Indicator values for ground-dwelling ant species collected along transects set in the soy field $(-100$ and $-50 \mathrm{~m})$, Cerrado edge habitat $(0$ and $50 \mathrm{~m})$ and Cerrado interior habitats $(100,150,200$, and $250 \mathrm{~m}$ ) in Balsas, Maranhão, northern Brazil. Only the significant indicator species are included $(p<0.05)$.

\begin{tabular}{lcccc}
\hline & Field & Edge & Interior & P-value \\
\hline Reserve 1 & & & & \\
Brachymyrmex patagonicus & - & - & 0.240 & 0.024 \\
Ectatomma brunneum & - & 0.332 & - & 0.021 \\
$\quad$ Ectatomma opaciventre & - & - & 0.250 & 0.007 \\
Reserve 2 & & & & \\
Camponotus crassus & - & - & 0.275 & 0.007 \\
Dorymyrmex pyramicus & - & 0.258 & - & 0.002 \\
Dorymyrmex spurius & - & 0.121 & - & 0.009 \\
Linepithema cerradense & - & - & 0.410 & 0.003 \\
Tapinoma melanocephalum & - & 0.229 & - & 0.004 \\
Cardiocondyla emeryi & 0.200 & - & - & 0.001 \\
Pseudomyrmex termitarius & - & 0.109 & - & 0.030 \\
Solenopsis sp. 1 & 0.375 & - & - & 0.001 \\
Solenopsis sp. 2 & - & 0.169 & - & 0.010 \\
Solenopsis sp. 3 & - & 0.169 & - & 0.004 \\
Wasmannia auropunctata & - & - & 0.171 & 0.020 \\
\hline
\end{tabular}

Few comparative data exist on the faunal communities' response to edges in Neotropical savannas (Spector \& Ayzama 2003). The Cerrado vegetation, being an open savanna habitat, may respond to edges in a different way than forests (Pivello et al. 1999). In fact, Joel L. de Queiroga (unpubl. data) did not detect edge effects on floristic composition (114 species of trees and shrubs) up to $400 \mathrm{~m}$ from the edge, as well as on microclimatic data (air humidity, air and soil temperature), in the same reserves we studied. Similarly, edge effects were not detected on richness or in species composition of dung beetles in a natural forest-Cerrado ecotone (DuRÃEs et al. 2005).

We have shown that the composition of ground-dwelling ants in the Brazilian Cerrado responds to habitat edges. The ants found at the edge are different from those found 50 $\mathrm{m}$ from it. However, as one moves further from the edge, this difference becomes insignificant. This finding is consistent with previous observations that the strongest influence of abiotic and biotic edge effects on invertebrates occurs within the first $50 \mathrm{~m}$ of the edges (DidHam 1997), and that edges affect litterdwelling ant species richness in a distance shorter than $50 \mathrm{~m}$ (Sobrinho \& Schoereder 2007). For example, the invasive Argentine ant, Linepithema humile (Mayr, 1868), appears to suppress native ants within $50 \mathrm{~m}$ of abrupt edges in southwestern California (HoLway 2005). Most empirical studies have found that edge effects penetrate less than $150 \mathrm{~m}$ into fragmented habi- tats - see e.g. Laurance (2000); but see Ewers \& Didham (2008) for large-scale edge effects on invertebrate communities.

Differences in species composition along the edges could be related to changes in factors that affect suitability of nesting sites, including degree of shading (vegetation cover), availability of nesting materials, soil moisture, soil depth, temperature, and availability of food resources in the neighborhood (BRAschler \& BaUR 2003). Thus, ant presence under edge-altered environments must be determined by the species physiological performance in disturbed environments.

By contrast, we did not find a consistent pattern for ant species richness or species occurrences responses from edge in the studied areas. Furthermore, there were obvious differences in community structure in soy field compared to edges and the interior of Cerrado. The indicator species analysis suggests that a few species occurred exclusively, or were more abundant at, certain points along the distances from the edge. Two highly generalist species, C. emeryi and Solenopsis sp. 1, were classified as soy species. Cardiocondyla emeryi is a cosmopolitan tramp species, widespread in the tropics (SEIFERT 2003), occurring in open areas and synanthropic habitats, feeding on dead insects, nectar or tending Hemiptera. Tapinoma melanocephalum, an edge species in our study, is also a widespread tropical tramp species, introduced by men throughout the world. Dorymyrmex pyramicus and D. spurius (edge classified species) prefer open habitats or highly disturbed areas where the soil is bare or covered by sparse grassy vegetation. Similarly, E. brunneum (an edge species) is widely distributed in Brazil, usually in areas with open vegetation such as forest edges or clearings, but also in cropland, pastures and secondary vegetation (Tofolo \& GianNotTi 2005).

It is interesting that $L$. cerradense, frequently associated with Cerrado habitats (WILD 2007), has been classified as an interior specialist species and may to be a trophic generalist. However, at least two species classified as interior specialists (C. crassus and $W$. auropunctata) are highly generalist species that inhabit a considerable range of Cerrado habitats (SILVESTRE et al. 2003). Brachymyrmex patagonicus, a tiny South American species, has been recently considered a matter of concern as it may represent a new ant pest in North America (MACGown et al. 2007). However, its biology is poorly known; workers tend hemipterous insects for honeydew and visit nectaries. E. opaciventre, another interior specialist species, is a common soil nester ant in Cerrado, primarily diurnal, preying mostly on termites and leaf-cutter ants (PIE 2004). In a Cerrado savanna in southeastern Brazil, the nests of E. opaciventre are most often found in more complex microhabitats, which may indicate nesting site choice by founding queens (PIE 2004).

Other studies have shown that ant communities might respond to edges, altering their species richness and/or composition, although there is no defined global pattern on how edges may affect ant communities (SObRINHO \& SCHOEREDER 2007). Ant abundance might increase (VASCONCELOS 1999) or might be 
kept unaltered at the edges (Kotze \& Samways 2001, Dauber \& Wolters 2004). Species richness might decrease (Carvalho \& VAsconcelos 1999, Kotze \& Samways 2001), increase (Majer et al. 1997) or remain unaltered towards the interior of forests (DAUBER et al. 2006, Sobrinho \& SCHOEREder 2007).

Higher ant species richness at edges may be due to the invasion by alien species or habitat generalists (SOBRINHO et al. 2003, SCHOEREDER et al. 2004), or by colonization by species better adapted to open areas, which may come from altered areas adjacent to pristine Cerrado habitat. Invasion from surrounding landscape may actually increase the total species richness at the edges. The higher diversity of plants and animals associated with edges and ecotones is known as the edge effect principle, which is widely referred to as a fundamental concept of ecology (Malcolm 1994, Didham 1997).

The present study has shown the significant response of the ant communities of the Cerrado biome to edges in terms of species composition. When examining species separately, we found that certain species of ants were more sensitive to edge effects than others. A better knowledge of the mechanisms through which edge effects alter ant communities will be useful for the development of strategies to mitigate harmful edge effects and to improve methods that can be used to evaluate the conservation value of legal reserves in which ants are diverse and abundant.

\section{ACKNOWLEDGMENTS}

We would like to thank our field assistants, Christiane Yamamoto and Bodo H. Dietz, Efraim Rodrigues (UEL), to all "Gerais de Balsas" personnel, to the Japanese Embassy in Brasilia and to JAICA (Japan International Cooperation Agency), in special Kazuhiro Yoshii, Takeshi Matsumura, and Shigeo Umetani. Our projects have been funded by Conselho Nacional de Desenvolvimento Científico e Tecnológico (CNPq) and Fundação de Amparo à Pesquisa do Estado de São Paulo (FAPESP, processes 07/01310-2 and 06/02190-8).

\section{LITERATURE CITED}

Agosti, D.; J.D. Majer; L.E. Alonso \& T.R. Schultz. 2000. Ants: standard methods for measuring and monitoring biodiversity. Washington, D.C., Smithsonian Institution Press, 280p.

Andersen, A.N. \& J.N. Majer. 2004. Ants show the way Down Under: invertebrates as bioindicators in land management. Frontiers in Ecology and Environment 2: 291-298.

Anderson, M.J.; R.B. Millar; W.M. Blom \& C.E. Diebel. 2005. Nonlinear multivariate models of successional change in community structure using the von Bertalanffy curve. Oecologia 146: 279-286.

Brandão, C.R.F.; R. Silvestre \& A. Reis-Menezes. 2000. Influência das interações comportamentais entre espécie de formigas em levantamentos faunísticos em comunidades de Cerra- do, p. 371-404. In: R.P MARTINs; T.M LEWINSOHN \& M.S BARBEITOS (Eds). Ecologia e comportamento de insetos. Rio de Janeiro, PPGE-UFRJ, Série Oecologia Brasiliensis, vol. 8.

BRASCHLER, B. \& B. BAUR. 2003. Effects of experimental small-scale grassland fragmentation on spatial distribution, density, and persistence of ant nests. Ecological Entomology 28: 651658.

Bridgewater, S.; J.A. Ratter \& J.F. Ribeiro. 2004. Biogeographic patterns, beta-diversity and dominance in the Cerrado biome of Brazil. Biodiversity and Conservation 13: 2295-2318.

Camargo, A.M. 1998. Partial report on Colonization Project Gerais de Balsas, MA 1997/1998. Brasília, DF, Embrapa Campo, Cia. de Promoção Agrícola, 30p.

Carvalho, K.S. \& H.L. Vasconcelos. 1999. Forest fragmentation in central Amazonia and its effects on litter-dwelling ants. Biological Conservation 91: 151-157.

Colwell, R.K. 2008. EstimateS: statistical estimation of species richness and shared species from samples. University of Connecticut, Storrs, software available online at: http:// purl.oclc.org/estimates [Acessed: 20/IV/2010].

Crawley, M.J. 2002. Statistical Computing: An Introduction to Data Analysis Using S-Plus. New York, John Wiley \& Sons, 761p.

DAuber, J. \& V. Wolters. 2004. Edge effects on ant community structure and species richness in an agricultural landscape. Biodiversity and Conservation 13: 901-915.

Dauber, J.; J. Bengtsson \& L. Lenoir. 2006. Evaluating effects of habitat loss and land-use continuity on ant species richness in seminatural grassland remnants. Conservation Biology 20: $1150-1160$.

Didham, R.K. 1997. An overview of invertebrate responses to forest fragmentation, p. 303-320. In: A.D. WATT; N.E. SтоRK \& M.D. Hunter (Eds). Forests and Insects. London, Chapman \& Hall, 406p.

Dufrêne, M. \& P. Legendre. 1997. Species assemblages and indicator species: the need for a flexible asymmetrical approach. Ecological Monographs 67: 345-366.

Durães, R.; W.P. Martins \& F.Z. VAZ-DE-Mello. 2005. Dung beetle (Coleoptera: Scarabaeidae) assemblages across a natural forest- Cerrado ecotone in Minas Gerais, Brazil. Neotropical Entomology 34: 721-731.

Ewers, R.M. \& R.K. Didham. 2008. Pervasive impact of largescale edge effects on a beetle community. Proceedings of the National Academy of Sciences of the United States of America 105: 5426-5429.

Ferraz, G.; G.J. Russell; P.C. Stouffer; R.O. Bierregaard Jr; S.L. Pimm \& T.E. Lovejoy. 2003. Rates of species loss from Amazonian forest fragments. Proceedings of the National Academy of Sciences of the United States of America 100: 14069-14073.

FrenCH, B.W. \& N.C. ElLIOT. 1999. Temporal and spatial distribution of ground beetle (Coleoptera: Carabidae) assemblages in grassland and adjacent wheat fields. Pedobiologia 43: 73-84. 
HolwaY, D.A. 2005. Edge effects of an invasive species across a natural ecological boundary. Biological Conservation 121: 561-567.

InGHAM, D.S. \& M.J. SAMwaYs. 1996. Application of fragmentation and variation models to epigaeic invertebrates in South Africa. Conservation Biology 10: 1353-1358.

JACOMINE, P.K.T. 1986. Mapas de solo do Brasil. Levantamento exploratório: reconhecimento dos solos do Estado do Maranhão. Rio de Janeiro, Embrapa, Serviço Nacional de Levantamento e Conservação de Solos, 1486p.

KLINK, C.A. \& R.B. Machado. 2005. Conservation of the Brazilian Cerrado. Conservation Biology 19: 707-713.

Kotze, D.J. \& M.J. Samways. 2001. No general edge effects for invertebrates at Afromontane forest/grassland ecotones. Biodiversity and Conservation 10: 443-466.

LAURANCE, W.F. 2000. Do edge effects occur over large spatial scales? Trends in Ecology and Evolution 15: 134-135.

Laurance, W.F. \& E. Yensen. 1991. Predicting the impacts of edge effects in fragmented habitats. Biological Conservation 55 : 77-92.

Laurance, W.F.; H.E.M. Nascimento; S.G. Laurance; A. Andrade; J.E.L.S. Ribeiro; J.P. Giraldo, T.E. Lovejoy; R. Condit; J. Chave; K.E. Harms \& S. D'Angelo. 2006. Rapid decay of treecommunity composition in Amazonian forest fragments. Proceedings of the National Academy of Sciences of the United States of America 103: 19010-19014.

MacGown, J.A.; J.G. Hill; M.A. Deyrup. 2007. Brachymyrmex patagonicus (Hymenoptera: Formicidae), an emerging pest species in the southeastern United States. Florida Entomologist 90: 457-464.

Malcolm, J.R. 1994. Edge effects in central Amazonian forest fragments. Ecology 75: 2438-2445.

Majer, J.D.; J.H.C. Delabie \& N.L. MacKenzie. 1997. Ant litter fauna of forest, forest edges and adjacent grassland in the Atlantic rain forest region of Bahia, Brazil. Insectes Sociaux 44: 255266.

Marchand, P. \& G. Houle. 2006. Spatial patterns of plant species richness along a forest edge: what are their determinants? Forest Ecology and Management 223: 113-124.

McGeoch, M.A.; B.J. Van Rensburg \& A. Botes. 2002. The verification and application of bioindicators: a case study of dung beetles in a savanna ecosystem. Journal of Applied Ecology 39: 661-672.

Myers, N.; R.A. Mittermeier; C.G. Mittermeier; G.A.B. Fonseca \& J. Kent. 2000. Biodiversity hotspots for conservation priorities. Nature 403: 853-858.

PIE, M.R. 2004. Foraging ecology and behaviour of the ponerine ant Ectatomma opaciventre Roger in a Brazilian savannah. Journal of Natural History 38: 717-729.

Pielou, E.C. 1984. The intepretation of ecological data: a primer on classification and ordination. New York, John Wiley \& Sons, 263p.

Pivello, V.R.; V.M.C. Carvalho; P.F. Lopes; A.A. Peccinini \& S. Rosso. 1999. Abundance and distribution of native and alien grasses in a "Cerrado" (Brazilian Savanna) biological reserve. Biotropica 31: 71-82.

Progea Engineering and Environmental Studies of Brazil. 1995. Assessment of environmental impact (EIA) Vol. I. Brasília, DF, Embrapa Campo, Companhia de Promoção Agrícola, 122p.

RoberTs, D.W. 2009. Labdsv: Ordination and Multivariate Analysis for Ecology. R package version 1.3-1. Available online at: http://ecology.msu.montana.edu/labdsv/R [Acessed: 20/IV/ 2010].

Schoereder, J.H.; T.G. Sobrinho; C.R. Ribas \& R.B.F. Campos. 2004. Colonization and extinction of ant communities in a fragmented landscape. Austral Ecology 29: 391-398.

Seifert, B. 2003. The ant genus Cardiocondyla (Insecta: Hymenoptera: Formicidae): A taxonomic revision of the $C$. elegans, C. bulgarica, C. batesii, C. nuda, C. shuckardi, C. stambuloffii, C. wroughtonii, C. emeryi, and C. minutior species groups. Annalen des Naturhistorischen Museums in Wien Serie B Botanik und Zoologie 104B: 203-338.

SiLVA, R.R.; C.R.F. BRANDÃo \& R. SilveStRe. 2004. Similarity between Cerrado localities in the Central and Southeastern Brazil based on the dry season ant fauna visiting baits. Studies on Neotropical Fauna and Environment 39: 191-199.

Silva, J.F.; M.R. Farinãs; J.M. Felfili \& C.A. KLINK. 2006. Spatial heterogeneity, land use and conservation in the Cerrado vegetation of Brazil. Journal of Biogeography 33: 536-548.

Silvestre, R.; C.R.F. Brandẽo \& R.R. Silva. 2003. Grupos funcionales de hormigas: El caso de los gremios del Cerrado, Brasil, p. 113-143. In: F. FERNÁNDEZ (Org.). Introducción a las Hormigas de la Región Neotropical. Bogotá, Instituto Humboldt, 424p.

Sobrinho, T.G. \& J.H. Schoereder. 2007. Edge and shape effects on ant (Hymenoptera: Formicidae) species richness and composition in forest fragments. Biodiversity and Conservation 16: 1459-1470.

Sobrinho, T.G.; J.H. Schoereder; C.F. Sperber \& M.S. Madureira. 2003. Does fragmentation alter species composition in ant communities (Hymenoptera: Formicidae)? Sociobiology 42: 329-342.

Spector, S. \& S. Ayzama. 2003. Rapid turnover and edge effects in dung beetle assemblages (Scarabaeidae) at a Bolivian Neotropical forest-savanna ecotone. Biotropica 35: 394-404.

Tabarelli, M.W. Mantovani \& C.A. Peres. 1999. Effects of habitat fragmentation on plant guild structure in the montane Atlantic forest of southeastern Brazil. Biological Conservation 91: 119127.

Tofolo, C.V. \& E. Giannotti. 2005. Population dynamics of Ectatomma brunneum (Hymenoptera, Formicidae) under laboratory conditions. Sociobiology 46: 627-636.

VASCONCELOS, H.L. 1999. Effects of forest disturbance on the structure of ground-foraging ant communities in central Amazonia. Biodiversity and Conservation 8: 409-420.

Viana, V.M.; A.A.J. Tabanez \& J.L.F. Batista. 1997. Dynamics and restoration of forest fragments in the Brazilian Atlantic moist 
forest, p. 351-365. In: W.F. Laurance \& R.O. BierRegaARd JR a generic model for delineating area of edge influences (D(Eds). Tropical forest remnants: ecology, management, AEI). Ecological Modelling 132: 175-190.

and conservation of fragmented communities. Chicago, University of Chicago Press, 505p.

ZHeng, D. \& J. CHEN. 2000. Edge effects in fragmented landscapes:

WiLD, A.L. 2007. Taxonomic Revision of the Ant Genus Linepithema (Hymenoptera: Formicidae). University of California Publications in Entomology 126: 1-151.

Submitted: 23.V.2010; Accepted: 02.I.2011.

Editorial responsibility: Marcio R. Pie 